\title{
AKTIVITAS ANTIMIKROBA DARI EKSTRAK DAN FRAKSI KARANG LUNAK Sarcophyton sp., DARI PERAIRAN PONTENG DESA TUMBAK MINAHASA TENGGARA TERHADAP MIKROBA PATOGEN Staphylococcus aureus, Escherichia coli, dan Candida albicans.
}

\author{
Triswa A. Mokodongan ${ }^{1)}$, Herny E. Simbala ${ }^{1)}$, Henki Rotinsulu ${ }^{1)}$ \\ ${ }^{1)}$ Program Studi Farmasi FMIPA UNSRAT Manado, 95115
}

\begin{abstract}
Soft coral sarcophyton sp., poruduces natural chemical compounds and is known as a natural product. These natural chemical compounds have the potential as a source of natural medicine. Soft coral sarcophyton sp., has antimicrobial, antibacterial, anti-fungal, anti-tumor,neurotoxic, and anti-inflammatory activities that are beneficialt to the pharmaceutical industry. This study aims to determine the biological activity of soft corals Sarcophyton sp., collected from the waters of Ponteng Tumbak Village, Southeast Minahasa Regency on microbial growth of staphylococcus aureus, Escherichia coli, and Candida albicans. Soft coral samples were macerated with $96 \%$ of ethanol solvent and partitioned liquid-liquid using methanol, chloroform, and n-hexane solvents. Staphylococcus aureus and Escherichia coli bacteria with a medium category, and were unable to inhibit the growth of the fungus Candida albicans.
\end{abstract}

Keywords: Sarcophyton sp., Antimicrobial, Staphylococcus aureus, Escherichia coli, Candida albicans.

\begin{abstract}
ABSTRAK
Karang lunak Sarcophyton sp., merupakan salah satu jenis karang lunak yang memproduksi senyawa kimia alami dan dikenal dengan istilah natural product. Senyawa kimia alami tersebut berpotensi sebagai sumber obat alami. Karang lunak Sarcophyton sp., mempunyai aktivitas antimikroba, antibakteri, anti fungi, anti tumor, neurotoksik, dan anti inflamasi yang bermanfaat bagi industry farmasi. Karang lunak Sarcophyton sp., ditemukan di daerah perairan Poteng Desa Tumbak Minahasa Tenggara. Penelitian ini bertujuan untuk mengetahui adanya aktivitas daya hambat pertumbuhan mikroorganisme dari Karang lunak Sarcophyton sp., terhadap mikroba Staphylococcus aureus, Escherichia coli, dan Candida albicans. Sampel diekstraksi metode maserasi dengan pelarut etanol dan fraksinasi menggunakan pelarut methanol, kloroform, dan n-heksan. Berdasarkan hasil penelitian menunjukkan bahwa masing-masing ekstrak dan fraksi mampu menghambat pertumbuhan bakteri Staphylococcus aureus dan Escherichia coli dengan kategori daya hambat sedang. Sedangkan masing-masing ekstrak dan fraksi pada Jamur Candida albicans tidak mampu menghasilkan aktivitas antibakteri.
\end{abstract}

Kata Kunci : Sarcophyton sp., Antimikroba, Staphylococcus aureus, Escherichia coli, dan Candida albican. 


\section{PENDAHULUAN}

Karang Lunak merupakan salah satu dari biota laut yang kaya akan senyawa bioaktif, seperti terpenoid, steroid, dan streroid glikosida. Ada sekitar 50\% ekstrak karang lunak yang menunjukan sifat racun pada ikan. Selain itu, karang lunak mengandung metabolit sekunder yang di hasilkan dari karang lunak yang memiliki aktivitas biologi seperti anti fungal, sitotoksik, anti neoplastic, antimikroba, inhibitor HIV, dan anti inflamantori (Radhika, 2006).

Karang lunak Sarcophyton sp. adalah salah satu genus Alcyonaria bertangkai besar dengan ukuran koloni yang besar pula. Ukuran koloni karang lunak ini dapat mencapai $1,5 \mathrm{~m}$, namun pada umumnya berukuran $10-20 \mathrm{~cm}$. Sarcophyton sp. dapat ditemukan dari rataan terumbu karang sampai ke kedalaman $15 \mathrm{~m}$ dengan konsentrasi pada kedalaman 3-10 m . karang lunak ini memiliki koloni yang berukuran besar, mempunyai tangkai berwarna putih atau senada dengan kapitalium. Kapitalium genus Sarcophyton berbentuk melebar seperti jamur atau bundar dengan tepi berlekuk atau melipat, permukaan halus seperti beludru. Bentuk koloni karang lunak ini bertangkai panjang atau pendek yang melekat di dasar (Fabricus dan Philip, 2001).

Genus Sarcophyton memiliki dimorfik, yaitu memiliki autosoid dan sifonosoid. Warna koloni genus ini adalah krem, coklat, kuning, atau hijau. Warna tersebut dihasilkan oleh sejumlah alga simbiotik (zooxanthellae) yang hidup di dalam jaringan tubuh karang. Sarcophyton sp. bereproduksi secara seksual dan aseksial. Reproduksi aseksual yang dilakukan oleh genus ini ada dua cara, yaitu fragmentasi atau memisah dan membentuk tunas (budding) (Fabricus dan Philip, 2001).

Sarcophyton sp., merupakan salah satu jenis karang lunak yang memproduksi senyawa kimia alami dan dikenal dengan istilah natural produk. Senyawa kimia alami tersebut berpotensi sebagai sumber obat alami. Hasil penelitian yang dilakukan oleh Sawant DKK (2006) menyatakan bahwa senyawa kimia aktif yang terdapat pada karang lunak Sarcophyton sp., menunjukkan aktivitas sebagai antimikroba, antibakteri, anti fungi, anti tumor, neurotoksik, dan anti inflamantori yang bermanfaat bagi industri farmasi.

Sarcophyton sp., adalah salah satu jenis karang lunak yang mampu menghasilkan bahan bioaktif. Bahan bioaktif yang terdapat pada Sarcophyton sp adalah sarcophine. Namun masalah serius dalam pengembangan senyawa bioaktif dari karang lunak adalah masalah suplai, karena untuk mendapatkan sejumlah relatif kecil senyawa bioaktif, diperlukan sejumlah besar karang lunak (Huda, 2011).

Mikroba patogen salah satu penyebab penyakit pada manusia dan makhluk hidup lainnya. Banyak usaha yang telah dilakukan untuk mengantisipasi pengaruh mikroba patogen tersebut yaitu dengan menemukan senyawa kimia yang dapat 
menghambat pertumbuhan dan membunuh bakteri (Juariah et al, 2014). Berdasarkan latar belakang tersebut di atas peneliti akan melakukan penelitian terhadap uji Aktivitas Antimikroba dari Ektrak dan Fraksi Karang Lunak Sarcophyton sp., yang di ambil dari perairan Poteng Minahasa Tenggara terhadap beberapa mikroba patogen Staphylococcus aureus, Escherichia coli, dan jamur Candida albicans.

\section{METODOLOGI PENELITIAN}

\section{Bentuk Penelitian}

Bentuk penelitian ini ialah eksperimen laboratorium yaitu menguji komponen yang diekstrak dari Karang Lunak Sarcophyton Sp., sebagai antimikroba yang diperoleh dari perairan Ponteng Desa Tumbak Minahasa Tenggara.

\section{Waktu dan Tempat Penelitian}

Penelitian ini dilaksanakan pada bulan Maret 2019 sampai Juli 2019 di Laboratorium Farmasi Lanjut Fakultas Matematika dan Ilmu Pengetahuan Alam Universitas Sam Ratulangi.

\section{Alat dan Bahan}

Alat

Alat yang digunakan dalam penelitian ini yaitu masker, sarung tangan, pisau, telenan, peralatan diving berupa snorkel, fins, tabung udara, dan masker, kantong plastic, alat-alat gelas, rotary evaporator, timbangan analitik, cawan petri, autoklaf, pinset, pembakar spritus, magnetic steerer, pipet tetes, batang pengaduk, Laminar Air Flow, lemari pendingin, incubator, kertas cakram, desikator, mikropipet, jangka sorong (kaliper), kamera untuk keperluan dokumentasi.

\section{Bahan}

Bahan-bahan yang digunakan yaitu Karang Lunak Sarcophyton sp, mikroba uji Staphylococcus aureus, Escherichia coli, dan Candida albicans, etanol 96\%, akuades, metanol, nheksan, kloroform, nutrient broth, nutrien agar, potato dextrose agar, Kloramfenikol, kertas cakram, label, spidol permanen, tissue, aluminium foil, kertas saring, kapas.

\section{Prosedur Kerja \\ Pengambilan Sampel}

Sampel Karang Lunak Sarcophyton sp, akan diambil di perairan Poteng Desa Tumbak Minahasa Tenggara menggunakan alat bantu (masker, tabung udara, snorkel, dan fins). Sampel dibersihkan dari kotoran yang menempel di sekitarnya, difoto lalu dimasukkan ke dalam kantong plastik, kemudian langsung dibawa ke Laboratorium Fitokimia dan Farmakognosi Program Studi Farmasi Universitas Sam Ratulangi. Kemudian sampel dipotong kecil-kecil dengan ukuran $1 \mathrm{~cm}^{2}$ dan diekstraksi dengan cara maserasi dengan etanol $96 \%$ lalu diberi label serta nomor sampel. Sebagian dari sampel disimpan dalam vial untuk diawetkan sebagai voucher untuk selanjutnya dideterminasi.

\section{Ekstraksi}

Ekstrak Karang Lunak

Sarcophyton sp, sebanyak $420 \quad \mathrm{~g}$ diekstraksi dengan menggunakan cara 
maserasi. Sampel dipotong kecil-kecil dengan ukuran $1 \mathrm{~cm}^{2}$ lalu dimasukkan ke dalam botol dan direndam dengan larutan etanol $96 \%$ sampai sampel terendam secara keseluruhan dan dibiarkan selama 24 jam. Sampel yang direndam disaring dengan menggunakan kertas saring menghasilkan filtrat 1 dan debris 1 . Debris 1 direndam dengan larutan etanol $96 \%$ sampai sampel terendam secara keseluruhan kemudian dibiarkan selama 24 jam. Sampel tersebut disaring menggunakan kertas saring menghasilkan filtrat 2 dan debris 2 . Debris 2 kemudian direndam dalam larutan etanol $96 \%$ sampai sampel terendam secara keseluruhan dan dibiarkan selama 24 jam, sampel tersebut disaring menggunakan kertas saring menghasilkan filtrat 3 dan debris 3. Filtrat 1, 2 dan 3 dicampur menjadi satu kemudian disaring, lalu dievaporasi menggunakan rotary evaporator sehingga didapat ekstrak kasar Karang Lunak Sarcophyton sp., kemudian ditimbang menggunakan timbangan analitik, diperoleh ekstrak etanol sampel sebanyak 9,3 g. Selanjutnya ekstrak etanol Karang Lunak Sarcophyton sp., digunakan dalam fraksinasi dan pengujian antimikroba.

\section{Fraksinasi}

Sebanyak 2 g ekstrak etanol Karang Lunak Sarcophyton sp., dimasukkan ke dalam Erlenmeyer dan dilarutkan dengan metanol $80 \%$ sebanyak $100 \mathrm{~mL}$. Setelah sampel larut, sampel dimasukkan ke dalam corong pisah dan ditambahkan pelarut n-heksan sebanyak $100 \mathrm{~mL}$. Sampel kemudian dikocok berulangkali dalam corong pisah hingga homogen. Sample dibiarkan hingga membentuk lapisan metanol $(\mathrm{MeOH})$ dan lapisan n-heksan. Masing-masing lapisan metanol dan lapisan n-heksan ditampung di dalam wadah yang berbeda. Lapisan n-heksan selanjutnya dievaporasi menggunakan rotary evaporator hingga kering, lalu ditimbang dengan timbangan analitik dan diperoleh fraksi n-heksan sebanyak 0,085 g. Selanjutnya lapisan metanol ditambahkan dengan akuades $100 \mathrm{~mL}$, kemudian dipartisi dengan pelarut kloroform menggunakan perbandingan 1:1 v/v setelah itu dikocok dalam corong pisah hingga homogen. Lapisan metanol dibiarkan hingga membentuk dua lapisan yaitu lapisan metanol dan lapisan kloroform. Masing-masing lapisan metanol dan lapisan kloroform ditampung ke dalam wadah yang berbeda. Lapisan kloroform dievaporasi menggunakan rotary evaporator hingga kering lalu ditimbang dengan timbangan analitik dan diperoleh fraksi kloroform sebanyak 0,120 g. Lapisan metanol yang ditampung pada wadah lain dievaporasi menggunakan rotary evaporator hingga kering lalu ditimbang dengan timbangan analitik dan diperoleh fraksi metanol sebanyak 0,080 g. Ketiga fraksi yang diperoleh akan digunakan dalam pengujian antimikroba. Rendemen-rendemen ekstrak dan fraksi dihitung dengan persamaan berat hasil ekstrak/fraksi dibagikan dengan berat awal ekstrak/fraksi kemudian dikalikan dengan $100 \%$. 


\section{Sterilisasi Alat}

Alat-alat gelas yang digunakan dalam penelitian aktivitas antimikroba ini disterilkan terlebih dahulu dengan menggunakan autoklaf pada suhu 121 ${ }^{\circ} \mathrm{C}$ selama 15 menit, pinset dibakar dengan pembakaran di atas api langsung dan media disterilkan di autoklaf pada suhu $121{ }^{\circ} \mathrm{C}$ selama 15 menit (Ortez, 2005).

\section{Pembuatan Media Cair B1}

Pepton 0,5 g, beef extract 0,3 g, natrium klorida $0,3 \mathrm{~g}$ dan akuades sebanyak $100 \mathrm{ml}$ diaduk sampai homogen kemudian disterilkan dalam autoklaf pada suhu $121^{\circ} \mathrm{C}$ selama 15 menit dan setelah itu didinginkan. Setelah dingin, media cair B1 di tutup dengan aluminium foil (Dwijendra et al, 2014).

\section{Kultur Mikroba}

Mikroba yang digunakan yaitu Escherichia coli, Staphylococcus aureus dan Candida albicans. Masingmasing mikroba diambil dari biakan murni menggunakan mikropipet sebanyak $100 \mu \mathrm{L}$ dan dimasukkan ke dalam masing-masing tabung reaksi yang sudah berisi media cair B1 sebanyak $1 \mathrm{ml}$ dan kemudian ditutup menggunakan aluminium foil. Setelah itu, diinkubasi dalam inkubator pada suhu $37^{\circ} \mathrm{C}$ selama 1 x 24 Jam (Dwijendra et al, 2014).

\section{Pembuatan Media Uji}

Pepton $0,5 \mathrm{~g}$, beef extract $0,3 \mathrm{~g}$, natrium klorida $0,3 \mathrm{~g}$, agar $1,5 \mathrm{~g}$ dan akuades sebanyak $100 \mathrm{ml}$ diaduk sampai homogen kemudian disterilkan di autoklaf pada suhu $121^{\circ} \mathrm{C}$ selama 15 menit (Dwijendra et al, 2014).

\section{Pembuatan Larutan Uji}

Larutan uji dibuat dengan cara 1 mg ekstrak kasar Karang Lunak Sarcophyton sp. dilarutkan dalam 200 $\mu \mathrm{L}$ metanol dan dikocok hingga homogen menggunakan vortex. Perlakuan yang sama dilakukan pada fraksi n-heksan, fraksi kloroform dan fraksi metanol (Ortez,2005).

\section{Pembuatan Kontrol Positif dan Kontrol Negatif}

Kontrol positif dalam pengujian aktivitas antimikroba ini menggunakan kloramfenikol paper disc. Kontrol negatif yang digunakan dalam penelitian ini yaitu menggunakan pelarut metanol, dengan cara membuat larutan stok metanol dengan mengambil sebanyak $200 \mu \mathrm{L}$ metanol kemudian di totolkan pada paper disc (Lalamentik, 2017).

\section{Pengujian Aktivitas Antimikroba}

Metode yang digunakan dalam penelitian ini yaitu metode difusi agar (disc diffusion Kirby and Bauer). Pada pengujian aktivitas antimikroba ini, cakram (paper disc) yang digunakan berukuran $6 \mathrm{~mm}$ dengan daya serap 50 $\mu \mathrm{L}$ tiap cakram. Sebanyak $300 \mu \mathrm{L}$ mikroba yang telah dikultur, dipipet dan diinokulasi pada $30 \mathrm{ml}$ media agar lalu diaduk hingga homogen dan kemudian dituangkan ke dalam cawan petri dan tunggu sampai media agar mengeras. Kemudian, larutan uji yang telah disiapkan ditotolkan pada masingmasing cakram dengan menggunakan 
mikropipet. Setelah agar mengeras, kertas cakram yang telah ditotolkan sampel Karang Lunak Sarcophyton sp., kontrol positif dan kontrol negatif diletakkan ke dalam cawan petri dengan menggunakan pinset. Selanjutnya, cawan petri diberi label dan diinkubasi dalam inkubator pada suhu $37^{\circ} \mathrm{C}$ selama 1 x 24 Jam (Ortez, 2005).

\section{Pengamatan dan Pengukuran Diameter Zona Hambat}

Pengamatan dilakukan setelah 24 jam masa inkubasi. Daerah pada sekitaran cakram menunjukkan kepekaan mikroba terhadap antibiotik atau bahan antimikroba yang digunakan sebagai bahan uji yang dinyatakan dengan diameter zona bening. Diameter zona bening diukur menggunakkan digital caliper. Kemudian zona bening yang telah diukur, dikategorikan berdasarkan pedoman Davis dan Stout (1971).

\section{Analisis Data}

Teknik pengolahan data dilakukan dengan model penyajian dalam bentuk tabel dan gambar .Aktivitas antibakteri di ukur dengan menggunakan jangka sorong skala millimeter berdasarkan zona hambat yang terbentuk, kemudian dirata-ratakan dari tiga kali pengujian.

\section{HASIL DAN PEMBAHASAN \\ Determinasi Sampel}

Determinasi karang lunak Sarcophyton sp., dilakukan di Fakultas Matematika dan Ilmu Pengetahuan Alam Program Studi Farmasi Universitas Sam Ratulangi.

\section{Preparasi Sampel}

Preparasi dilakukan dengan mengambil sampel karang lunak Sarcophyton sp., dari perairan Ponteng Desa Tumbak Minahasa Tenggara dilakukan dengan dipotong kecil-kecil berbentuk dadu

\section{Ekstraksi Karang Lunak Sarcophyton}

sp.

Ekstraksi dilakukan selama $3 \mathrm{x}$ 24 jam, dan setiap 24 jam ekstrak karang lunak Sarcophyton sp disaring dan dimaserasi kembali dengan memakai pelarut yang baru, hal ini disebut dengan remaserasi. Massa ekstrak beserta rendemen yang dihasilkan dalam proses ekstraksi dapat dilihat pada Tabel 1.

Tabel 1. Rendemen Ekstrak Karang

\begin{tabular}{ccccc}
\multicolumn{3}{l}{ Lunak } & \multicolumn{3}{c}{ Sarcophyton sp. } \\
\hline N & Samp & Massa & Rendem & Warn \\
o & el & $\begin{array}{c}\text { Ekstra } \\
\text { k (gr) }\end{array}$ & en (\%) & a \\
& & & $\begin{array}{c}\text { Samp } \\
\text { el }\end{array}$ \\
& & & & Cokla \\
1 & Ekstra & 9,3 & 2,21 & t \\
& k & & &
\end{tabular}

\section{Fraksinasi Karang Lunak}

\section{Sarcophyton sp}

Setelah dilakukan maserasi selanjutnya dilakukan proses fraksinasi dimana metode penelitian ini menggunakan metode fraksinasi caircair. Pelarut yang digunakan untuk fraksinasi ini yaitu n-heksan, kloroform, dan metanol. Massa fraksi beserta rendemen yang dihasilkan dalam proses fraksinasi dapat dilihat pada Tabel 2. 
Tabel 2. Massa Fraksi Beserta Rendemen

\begin{tabular}{|c|c|c|c|c|}
\hline $\begin{array}{l}\mathrm{N} \\
\mathrm{o}\end{array}$ & Sampel & $\begin{array}{c}\text { Mass } \\
\text { a } \\
\text { Ekstr } \\
\text { ak } \\
\text { (gr) }\end{array}$ & $\begin{array}{l}\text { Rendem } \\
\text { en }(\%)\end{array}$ & $\begin{array}{c}\text { Warn } \\
\text { a } \\
\text { Samp } \\
\text { el }\end{array}$ \\
\hline 1 & $\begin{array}{l}\text { Fraksi } \\
\text { N- } \\
\text { Heksan }\end{array}$ & $\begin{array}{l}0,080 \\
\text { gr }\end{array}$ & $4,25 \%$ & $\begin{array}{l}\text { Cokl } \\
\text { at } \\
\text { Keru } \\
\text { h }\end{array}$ \\
\hline 2 & $\begin{array}{l}\text { Fraksi } \\
\text { klorofo } \\
\text { rm }\end{array}$ & $\begin{array}{l}0,120 \\
\text { gr }\end{array}$ & $6,00 \%$ & $\begin{array}{l}\text { Cokl } \\
\text { at }\end{array}$ \\
\hline 3 & $\begin{array}{l}\text { Fraksi } \\
\text { Metano } \\
1\end{array}$ & $\begin{array}{l}0,085 \\
\text { gr }\end{array}$ & $4,00 \%$ & $\begin{array}{l}\text { Cokl } \\
\text { at } \\
\text { Beni } \\
\text { ng }\end{array}$ \\
\hline
\end{tabular}

Table di atas menunjukan bahwa dalam senyawa karang lunak Sarcophyton sp., terdapat banyak senyawa yang bersifat semi polar.

\section{Uji Aktivitas Antimikroba Karang}

\section{Lunak Sarcophyton sp}

Pada pengujian aktivitas antimikroba dengan menggunakan mikroba uji Staphylococcus aureus, Escherichia coli, dan Candida albicans dari ekstrak etanol, fraksi metano, fraksi n-heksan dan fraksi klorofom menggunakan metode difusi agar.

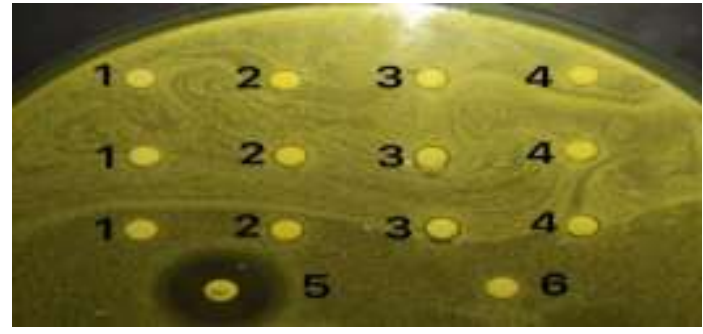

Gambar A. Staphylococcus aureus

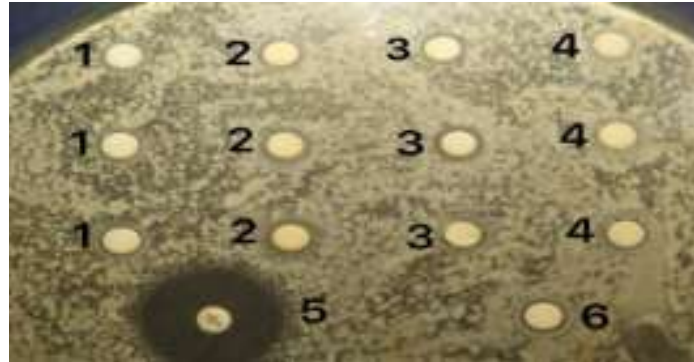

Gambar B. Escherichia coli

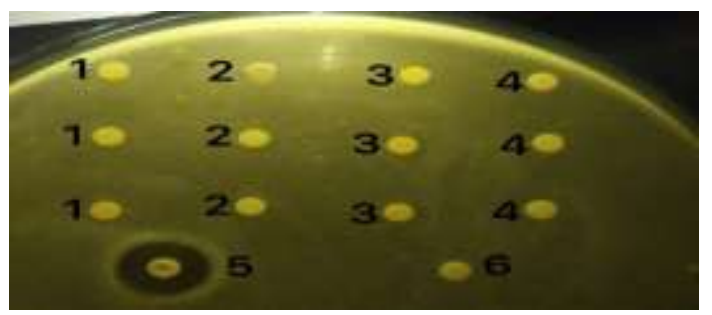

Gambar C. Candida albicans

Gambar 1. Hasil Uji Aktivitas Antimikroba dari Ekstrak dan Fraksi Karang Lunak Sarcophyton sp. :(A). Staphylococcus Aureus, (B). Escherichia coli dan (C) Candida albicans.

Keterangan (1). Fraksi metanol,

(2). Fraksi kloroform, (3). Fraksi n.heksan, (4). Ekstraksi etanol, (5). Kontrol Positif, (6) Kontrol Negatif

Tabel 3. Hasil rata-rata Aktivitas Antimikroba Ekstrak dan Fraksi Karang Lunak

\begin{tabular}{|c|c|c|c|c|c|c|c|}
\hline \multirow[b]{2}{*}{ Mtikrita } & \multirow[b]{2}{*}{ D7angan } & \multicolumn{6}{|c|}{ Rata-Rata Diameter (mu) } \\
\hline & & EM & FK & EN & EE & + & - \\
\hline \multirow[t]{2}{*}{ Sat } & 1 & 6.30 & 7,00 & 7,00 & 6,25 & 20,00 & 0,00 \\
\hline & II & 6.30 & 7,00 & 700 & 6,25 & 2000 & 0.00 \\
\hline \multirow{3}{*}{$\begin{array}{l}\text { Jumiab } \\
\text { Rata } \\
\text { rata }\end{array}$} & III & 6.25 & 7,00 & $7, \infty$ & 6.25 & 20,00 & 0,00 \\
\hline & I & 18.85 & 2100 & 21,00 & 18,75 & 60,00 & 0,00 \\
\hline & $\bar{x}$ & 6,28 & 7,00 & $-7,00$ & 6.25 & 20,00 & 0,00 \\
\hline \multirow[t]{2}{*}{ Ee } & 1 & 7,00 & 7,20 & 6,10 & 700 & 23,00 & 0,00 \\
\hline & tा & 7,06 & 7,30 & 6.25 & 700 & 23,00 & 0.00 \\
\hline \multirow{3}{*}{$\begin{array}{l}\text { Jamlah } \\
\text { Rata } \\
\text { sata }\end{array}$} & III & 7,00 & 7,20 & 6,25 & 700 & 23,00 & 0,00 \\
\hline & $\Sigma$ & 21,00 & $2 t, 70$ & 18,6 & 21,00 & 69,00 & 0,00 \\
\hline & $\bar{x}$ & 7,00 & 7.23 & 6,20 & 700 & 23,00 & 0,00 \\
\hline \multirow[t]{2}{*}{$\mathrm{Ca}$} & 1 & 0.00 & 0.00 & 0,00 & 0,00 & 17,00 & 0.00 \\
\hline & II & 0,00 & 0,00 & 0,00 & 0,00 & 17,00 & 0.00 \\
\hline \multirow{3}{*}{$\begin{array}{l}\text { Jumilah } \\
\text { Rata- } \\
\text { rata }\end{array}$} & III & 0.00 & 0.00 & 0,00 & 0,00 & 1700 & 0,00 \\
\hline & I & 0.00 & 0,00 & 0,00 & 0,00 & 51,00 & 0,00 \\
\hline & $\bar{x}$ & 0,00 & 0,00 & 0,00 & 0,00 & 17,00 & 0.00 \\
\hline
\end{tabular}


Keterangan;(Ec)Escherichia coli, (Sa)Staphylococcus aureus, (Ca)Candida albicans, (EE) Ekstrak etnol, (FH) Fraksi heksan, (FK) Fraksi kloroform, (FM) Fraksi metanol, (+) kontrol positif, $(-)$ kontrol negatif, $(\in)$ jumlah zona bening, $(\bar{X})$ jumlah rata-rata zona bening

Pada penelitian ini ekstrak etanol fraksi metanol fraksi n-heksan dan fraksi klorofom merupakan ekstrak dan fraksi yang efektif dalam menghambat pertumbuhan bakteri Gram positif Staphylococcus aureus bakteri Gram negatif Escherichia coli sedangkan untuk jamur Candida albicans tidak efektif dalam penghambatan.

Pada pengujian aktivitas antimikroba dari sempel karang lunak Sarcophyton sp penggolongan kekuatan daya antimikroba digolongkan menurut pedoman Davis and Stout (1971) yang ditunjukan pada tabel 4 .

Tabel 4. Kategori Kekuatan Daya Antimikroba Berdasarkan Pedoman Davis and Stout.

\begin{tabular}{cc}
\hline $\begin{array}{c}\text { Diameter Zona } \\
\text { Bening(mm) }\end{array}$ & Kategori \\
\hline$\geq 20$ & Sangat Kuat \\
$10-20$ & Kuat \\
$5-10$ & Sedang \\
$\leq 5$ & Lemah \\
\hline
\end{tabular}

Dari hasil yang diperoleh menunjukan bahwa ektra etanol fraksi metanol, fraksi klorofom dan fraksi nheksan efektif dalam menghambat pertumbuhan mikroba uji Staphylococcus aureus dan Escherchia coli sedangkan untuk jamur Candida albicans tidak efektif dalam penghambatan.

\section{KESIMPULAN}

Menurut hasil penelitian yang telah dilakukan dapat disimpulkan bahwa karang lunak Sarcophyton sp yang diperoleh dari perairan Desa Tumbak Minahasa Tenggara memiliki aktivitas antimikroba pada bakteri Gram positif Staphylococcus aureus dan Escherchia coli yang tergolong aktifitas yang sedang dan untuk jamur candida albicans tidak memiliki aktivitas antimikroba.

\section{SARAN}

Hasil dan pembahasan dari aktivitas antimikroba ekstrak dan fraksi karang lunak Sarcophyton sp, dapat diberikan saran yaitu perlu dilakukan penelitian tentang uji antimikroba dengan metode pengujian yang berbeda atau dengan menggunakan mikroba yang berbeda.

\section{DAFTAR PUSTAKA}

Davis, W. W., T.R. Stout. 1971. Disc plate method of microbiological assay. Journal of microbiology 22: 659-665. 
Fabricius, K. Dan P. Aldersade. 2001. Soft Coral And Sea Fans: A Comprehensive Guide to Tropical Shallow- Water Genera of the Central-West Pasific, the indian Ocean and The Red Sea. Institut of Marine Science. Twonsvile. (Diakses Mei 2019)

Huda, C. 2011. Penapisan Aktifitas Antibakteri dan Bakteri Yang Berasosiasi Dengan Karang Lunak Sarcophyton sp. Jurnal. Program Studi Ilmu Kelautan. Fakultas Matematika dan Ilmu Pengetahuan Alam. Universitas Sriwijaya.

Juariah, S., Suryanto, D., dan Jamilah , 1. 2014. Aktivitas Antibakteri Spesies Asterias Forbesii terhadap Beberapa Jenis Bakteri Patogen. Jurnal Berkala Perikanan Terubuk.

Lalamentik, G. 2017. Aktivitas Antibakteri Ekstrak Karang Lunak Klyxum sp. yang Diperoleh dari Teluk Manado. [Skripsi]. Program Studi Farmasi FMIPA Universitas Sam Ratulangi, Manado.

Ortez, J. H. 2005. Disk Diffusion testing in manual of antimicrobial susceptibility

Radhika, P. 2006. Chemical constituens and biological activities of the soft coral of genus Cladiella: A review.
Biochemical Systematics and Ecological 34: 781-789. (Diakses Mei 2019)

Sawant, S., Youssef, D., Mayer, A., Sylvester, $\quad$ P. 2006. Anticancer and Antinflamantory Sulphur ontaining Semisyntethic Derivates of Sarcophine. Chem Phar. 54(8):11191123. 